\title{
STATUTORY SOCIAL SERVICES: AN INTEGRAL PART OF DEVELOPMENTAL SOCIAL WELFARE SERVICE DELIVERY ${ }^{1}$
}

\section{A Lombard, WC Kleijn}

\section{INTRODUCTION}

The adoption of a developmental approach to social welfare in South Africa in 1997 earmarked a commitment by the South African government and the social welfare sector to transform social welfare services within the context of the broader transformation agenda of South African society.

The mandate for developmental social services is outlined in the White Paper for Social Welfare (1997) (Department of Social Development, 2004a:5; Streak \& Poggenpoel, 2005:3). This mandate entails a deliberate shift from the "racial, paternalist and residual apartheid welfare system [...] to the developmental approach to social welfare [which] was intended to modernise the welfare system to be more just, equitable, participatory and appropriate in meeting the needs of all South Africans (Patel, 2005:1). The challenge for social welfare organisations after 1994 was to improve service delivery and make services more accessible and responsive to the needs of the vast majority of the population (Department of Social Development, 2004a:5). Streak and Poggenpoel (2005:4) indicate that after 1994, one of the most difficult, yet urgent, tasks facing the first democratic government was to transform and extend the social welfare system.

Moving from the old to the new is always challenging in any sphere, including the welfare context. The call for a development approach, in the words of Patel (2005:3), “...has caused considerable tension and uncertainty about the management of change from the old system to the new". One of many challenges in this regard is providing statutory social work services within a developmental approach.

This challenge is compounded by the realities of practice facing social work as the primary social service profession that intervenes on statutory level, that is, the high case loads per social worker and the ever-increasing demand for statutory services (Floris, 2005; Du Toit, 2006).

The social work profession will only be able to claim that social service delivery has transformed to a developmental approach if the "fit" of statutory services in the "development basket" of social service delivery is clearly demarcated and recognised as such by social work educators and practitioners.

Streak and Poggenpoel (2005:4) regard social welfare services as including “....all those services excluding social security and research - that are delivered by departments of social development (with the assistance of non-governmental agencies) to support, empower and fulfil the rights of vulnerable South Africans as well as help prevent vulnerability". Patel (2005:5) regards social welfare services as one of two key social development programmes, the other one being social security. The Integrated Social Service Delivery Model of the Department of Social Development (2005a) divides developmental social services into three work streams, i.e. social welfare services, professional support and community development. What is of importance for the argument of this article is that none of these references excludes statutory social services from "social welfare services".

1 We would like to acknowledge Mrs. Margot Davids, Chief Director: Statutory Social Work, Department of Social Development, Gauteng Provincial Government for her comments on the previous draft. 
In fact, Streak and Poggenpoel (2005:3) indicate very specifically that the kinds of services that traditionally form part of "social welfare services" include, amongst others, interventions (including children's court services) in respect of children who are victims or at risk of abuse, neglect or exploitation, living and/or working on the streets, affected by HIV/AIDS, as well as foster care placements and the management of children's homes.

If statutory social services are incorporated under "social welfare services", then they are without doubt also included in the policy shift to provide social welfare services within a developmental approach. The incorporation of statutory social services under the term "social welfare services" is in line with the call in the White Paper for Social Welfare (1997:56) to conceptualise and deliver all social services within an integrated and developmental paradigm. The Chief Director: Statutory Social Work, Department of Social Development, Gauteng Provincial Government, Mrs M Davids, confirmed during a personal discussion (3 February, 2005) that government expects statutory social work services to be delivered from a developmental approach.

The first step towards statutory social service delivery within a development framework is recognising that statutory social services are included in the "basket of developmental social welfare service delivery". The question is thus not whether statutory social services can or should be developmental, but how to provide them within a developmental approach and what the challenges are to achieve this, given practice realities.

Research findings of a study on developmental statutory social services by Kleijn (2004) indicated that social work practitioners do think it is possible to do statutory work from a developmental perspective, provided that an enabling environment is created for this purpose. Creating an enabling environment, however, demands a deliberate re-focus from the current practice of statutory social service delivery, to developing a clear vision of what should be changed and approached differently to achieve a paradigm shift towards developmental statutory social service delivery.

Finding the "how" is not only a challenge for statutory social services, but has been the key challenge in establishing the overall shift to a developmental social welfare paradigm for social service delivery since the adoption of the White Paper for Social Welfare in 1997. Although there is significant evidence of successes in developmental social service delivery (Green \& Nieman, 2003; Lombard, 2005; Patel, 2005), the impact in relation to the increasing demand for statutory services has not yet been researched and made known.

This article intends to initiate a scholarly debate on the context and place of statutory social services in the developmental social service delivery framework and to highlight the many challenges that need to be addressed to create an enabling environment conducive to implementing developmental statutory social services. For the purpose of this article, the focus will be on child and family welfare services as social workers are highly involved in statutory interventions in this area of service delivery (Loffell in Du Toit, 2006).

\section{TOWARDS DEFINING DEVELOPMENTAL STATUTORY SOCIAL SERVICES}

The mandate for developmental statutory social services is provided by the key directives for transformation of the social welfare sector, namely: (1) a deliberate shift from a residual to a developmental approach; (2) a shift from individuals to the masses; and (3) a shift to integrated, holistic social service delivery (RSA Ministry of Social Welfare and Population Development, 1997; Department of Welfare, 1999; Department of Social Development, 2005a).

In order to make these shifts, the nature and extent of statutory social services within a development approach need to be conceptualised within the historical context of statutory service 
delivery. Embedded in this argument is the direct link between casework and statutory work (Sturgeon, 1998:27), and the historic link between casework and the residual social welfare approach and hence remedial social services.

\section{Legitimacy of casework in developmental paradigm}

Sturgeon (1998:26) asserts that casework is generally taken to mean work with individuals and families on a one-to-one basis or, in generic terms, micro-level interventions. The misuse of casework due to the power imbalances of the apartheid regime (Sturgeon, 1989:26) should not bring into question the relevance of casework within a developmental context, when appropriate. What is in question is the social welfare policy approach that informs how casework, as an intervention strategy, is applied. To understand and apply the shift of statutory social services from a residual social welfare policy perspective to an integrated, development practice framework requires a clear distinction between social welfare policy approaches and social welfare intervention methods, approaches and strategies for social service delivery. As opposed to the stigma attached to the residual social welfare approach where clients are blamed for their predicament because of personal inadequacies, ill-activities, or sins (Zastrow, 2004:10), the developmental policy approach to social welfare views the client as a person with human rights and strengths that can be unlocked through solving his/her own problems. It advocates social interventions that contribute positively to economic development; and it promotes the active role of government in economic and social planning, and the integration of economic and social development for the benefit of all members (Zastrow, 2004:11).

From a developmental social welfare approach, the focus of social service delivery moves away from the "remedial" or "developmental" service debate. It has long been recognised in South Africa that social workers will always have the dual responsibility of being people helpers (therapy approach) and social reformers (social reform approach) (Billups, 1990:22; Lombard, 2005:225). Remedial services are not contradictory to a developmental approach, since a developmental approach does not change the fact that there will always be people in need of individual care and services. A globally recognised scholar on the developmental approach, James Midgley (1984) (in Elliott, 1993:28), cautions that "overemphasis on a social development approach has led to the neglect of remedial programmes in some developing countries at considerable cost to vulnerable groups".

It is thus not the remedial services and casework that are in question, but their association with the residual social welfare policy. Being the primary intervention method during the apartheid regime, casework in South Africa is attached to stigma and deficiency. Casework is a method of intervention and cannot be discarded as such, especially when a practice situation demands it as the most appropriate strategy within a developmental social welfare policy framework.

A development perspective to statutory social services implies that casework should be approached from the challenge that there are other ways to approach problems that need "individual attention" (Sturgeon, 1998:25). An abused child can thus be helped individually while societal structures are simultaneously reformed through community-based initiatives (Elliott, 1993:31). Pittman-Munke (1999:225) dispels any doubt that casework, and therefore statutory social services, can be developmental by indicating how the integrated model, developed in the late nineteenth century by one of the pioneers in the professionalisation of social work, Mary Richmond, is still relevant today. This integrated model "demonstrates how social casework and social reform can serve to reinforce and support one another for the betterment of society" (Pittman-Munke, 1999:205). Elliott (1993:31) argues that a child who needs protection can be regarded as underprivileged and a victim of social injustice. 
This conclusion is in line with the integrated perspective of the developmental approach as outlined in the White Paper for Social Welfare (RSA Ministry of Social Welfare and Population Development, 1997:20) which conceptualises the framework for social service delivery in South Africa as the provision of comprehensive, generic and integrated services which emphasise the relationship between the person and his or her environment.

One way of shifting the association of remedial services and casework from a residual, casework perspective to an integrated developmental paradigm, is to approach social welfare services from a holistic framework. The Integrated Service Delivery Model (Department of Social Development, 2005a: 36) groups the core social services into five broad categories:

- Promotion and prevention services

- $\quad$ Protection services

- Rehabilitation services

- Continuing care services

- Mental health and addition services (Potgieter, 1998:114 and RSA Ministry of Social Welfare and Population Development, 1997:57).

Within the above broad categories, "statutory services" is incorporated under protection services. This category is helpful in conceptualising the shift of statutory social services from a residual, casework perspective to an integrated, comprehensive approach. Under the umbrella of protection services, statutory social services include more than statutory intervention, i.e. the legal procedure and process. September $(2005: 27)$ refers to statutory procedures as the "formal child protection system". From a protection perspective, statutory social services are targeted at all intervention levels (micro, mezzo and macro) and incorporate various intervention strategies ranging from formal (statutory) intervention to therapy, organisational change, social education, social action (Elliott, 1993:31) and community programmes such as the neighbourhood-based initiatives of the Child and Youth Research and Training Programme (CYRTP) of the University of the Western Cape (September, 2005).

Within an integrated service delivery framework, statutory interventions cannot therefore be regarded or applied as isolated interventions. Streak and Poggenpoel (2005:6) elaborate on this by pointing out that a developmental approach to social welfare emphasises integrated multiprolonged interventions that build self-reliance and foster participation in decision-making at individual, family and community level.

Against the background of this discussion, statutory social services can be defined from a narrow, residual, stigmatised perspective or from a broader developmental, protective services approach.

\section{Residual vs. developmental approach}

From a residual social welfare policy perspective, statutory social services fit the narrow definition of statutory work, i.e. a legal intervention where "an individual has become involved in some form of court case and will be "in statutory process" until the court proceedings have been finalised" (Department of Social Welfare, 1999:13). Services are aimed at supporting and strengthening the individual involved (Department of Social Development, 2005a:18-20). This intervention depicts the multiple and complex picture of over 8 million children living in residential care worldwide (International Save the Children Alliance, 2003:1) who need support as individuals, as a result of a statutory process. 
From a developmental social welfare policy perspective statutory social services are not only a micro-level statutory intervention, but linked to a macro-level, focusing on how socio-economic problems, globalisation, poverty, migration, HIV/AIDS, crime, disability, family difficulties and armed conflict affect the ability of families to raise children (International Save the Children Alliance, 2003:1; Streak \& Poggenpoel, 2005:6). A statutory intervention can therefore not be isolated from the reasons why the intervention was done in the first place.

Based on experience, the International Save the Children Alliance (2003:14) reports that the main reasons for children growing up outside families, at the household level, appear to be:

- Death or disappearance of one or both parents or carers

- Divorce, separation and remarriage

- Migration of mothers for employment

- Poverty

- Behaviour of the child and relationship difficulties

- Discrimination, particularly with regard to disability and gender

- Abuse and neglect of the child within the family; alcohol and drug abuse

- $\quad$ Parents or the family unable to provide care.

The definition of statutory work in the New Dictionary for Social Work (Terminology Committee, 1995:62) is more in line with this broader focus and defines statutory work as a "[s]pecialised field in social work aimed at improving the social functioning of individuals, families and communities by applying administrative procedures prescribed by a written law of a legislative body". This definition clearly emphasises the link between an individual (child) and his/her family with the community of which they are an inherent part. This broad perspective of statutory social services is reflected in the "statutory process" level of social service delivery as outlined in the Financing Policy for Developmental Social Welfare Services (Department of Social Welfare, 1999:13) which incorporates a broader focus than the individual: "Services at this level are aimed at supporting and strengthening communities, families, children, [...] and are based on a strong recognition [...] that a specific range of services needs to be available". For the purpose of this article, developmental statutory social services are defined within this broader framework as follows.

\section{Defining developmental statutory services}

Developmental statutory social services are protection services aimed at providing, in an integrated manner, all the core social welfare services (including formal protection services, i.e. the administrative procedures prescribed by legislation, as well as those services required to address the needs and concerns which created and initiated the statutory process in the first place) needed by the child, the family and the community to improve their social functioning in relation to the demands created in their interaction with their environment.

The premise and ultimate aim of developmental statutory services is to preserve families (in their different forms and shapes ${ }^{2}$ ). The $3^{\text {rd }}$ Draft National Policy for Families (Department of Social

\footnotetext{
${ }^{2}$ Recognising that there are many forms of families, the "parent" refers to the person or persons in whose care the child was prior to the initiation of the statutory process, be that the parent/s, guardian/s, or custodian/s.
} 
Development, 2004b:73) indicates that the rationale of family preservation strategies is "the belief that children and young people need a family in which to develop." According to the National Coalition for Child Protection Reform (2003), family preservation "refers to a systematic determination of those families in which children could remain in their homes or be returned home safely, and provision of the services needed to ensure that safety."

Developmental statutory social services are embedded in a human rights approach and draw from strength and empowerment theories and practice models such as social development, sustainable livelihoods and sustainable development. September (2005:30) aptly defines the term "integrated development" as bringing together "the insights of the last decade about the importance of peoplecentredness, human rights, social justice, equity and sustainable development". The link between development and integration with regard to statutory social services are enshrined in the broader social service delivery framework for developmental social services.

\section{SERVICE DELIVERY FRAMEWORK FOR DEVELOPMENTAL STATUTORY SOCIAL SERVICES}

Social service delivery lies on a continuum of care that ranges from prevention to early intervention, statutory intervention and finally reconstruction and aftercare (Department of Social Welfare, 1999:12-13; Department of Social Development, 2005a:18-20). Within an integrated developmental approach, the "continuum of care" should rather be seen as an open system/cycle as opposed to a linear process. The Integrated Service Delivery Model (Department of Social Development, 2005a:18-20A) concurs as follows: “... whilst these levels seem to be distinct, a client may enter [or exit] the system at any of the levels and the levels may overlap in practice".

The description of the "Statutory Process" level of social service delivery in the Financing Policy for Developmental Social Welfare Services (Department of Welfare, 1999:13) describes this approach to statutory work as follows: "Any service to children, youth, families [...] could be at one or more of the service levels (early intervention and the continuum of care and development) and should ensure that special development areas are integrated where they are relevant to the service participants".

Social services within the realm of protection services always include a statutory intervention and therefore will be used as an entry level for discussing the social delivery framework for developmental statutory social services.

\section{Statutory intervention as entry level}

Within the context of child and family welfare services, it is the responsibility of social workers to remove a child in need of care and protection. The new Children's Bill (Bill 70D of 2003) in section 150(1) provides a good overview as to the reasons for statutory intervention which states that a child is in need of care and protection if, the child -

(a) has been abandoned or orphaned and is without any visible means of support;

(b) displays behaviour which cannot be controlled by the parent or care-giver;

(c) lives or works on the streets or begs for a living;

(d) is addicted to a dependence-producing substance and is without any support to obtain treatment for such dependency; 
(e) has been exploited or lives in circumstances that expose the child to exploitation;

(f) lives in or is exposed to circumstances which may seriously harm that child's physical, mental or social well-being;

(g) may be at risk if returned to the custody or the parent, guardian or care-giver of the child as there is reason to believe that he or she will live in or be exposed to circumstance which may seriously harm the physical, mental or social well-being of the child;

(h) is in a state of physical or mental neglect; or

(i) is being maltreated, abused deliberately neglected or degraded by a parent, a care-giver, a person who has parental responsibilities and rights or a family member of the child or by a person under whose control the child is.

In addition, sub-section 2 indicates that a child may be in need of care and protection and must be referred for investigation by a designated social worker where

(a) a child is a victim of child labour; and

(b) a child is in a child-headed household.

Having the law as the mechanism to perform a statutory intervention (Sturgeon, 1998:26; Landman, 2004:79) is where the greatest challenge lies for social workers to shift from deficiencybased approaches and interventions to strength and empowerment approaches and strategies. Social workers could easily abuse their power by making decisions for clients. A decision to remove a child may not be taken lightly, as the Department of Welfare (1998:29) indicates: "The natural bond between parent and child should only be disrupted in order to provide for the care and protection of the child where this would be in his or her best interests, otherwise, it will be an immoral and improper exercise of the powers of the State."

From a developmental perspective, social workers should inform clients of their rights to information, participation and decision-making, including their right to legal representation (Wexler, 2003:54). All children in South Africa have rights that are set out in the Bill of Rights in the Constitution (Act 108 of 1996), as well as in the Convention on the Rights of the Child (CRC), 1996, and the African Charter on the Rights and Welfare of the Child (ACRWC) (Streak \& Poggenpoel, 2005:5). Article 12 of the CRC places an obligation on governments to ensure that children's views are sought and considered in all matters that affect their lives. Children of all ages should be allowed to express their views and in ways with which they are comfortable (International Save the Children Alliance, 2003:13). According to the said Alliance, children do not generally participate in decisions regarding their admission to or discharge from residential care, or in relation to their lives in an institution. The child and the family have the right to know in what way the statutory intervention will protect the child from harm (Van Niekerk, 1998:32) and the community has the right to indicate how it can protect a child by keeping him/her in the community or support the child and the family once they have been reintegrated.

Even in emergency removals, the rights of the child and the family to participate in decisions regarding the statutory process and the desired services should be respected. Patel $(2005: 157)$ emphasises that individual and client populations are active partners with those working for the realisation of rights and together they have a shared interest (Department of Social Development, 2005a:23).

If children, families and communities know they have rights, and moreover know what these rights are within a statutory intervention and protection services context, it is more likely that they 
will participate and take responsibility as partners in the intervention process. Clients also have the right to be informed about the reasons for any delays in submitting court reports and that they are protected by law from improper professional conduct by social workers.

Empowered clients will also impact on how social workers conduct their investigations. They will facilitate opportunities for social workers to interview all the people who may be able to provide insight into the family in order to make well informed recommendations and will insist on having insight into the final report. Investigations regarding alternative placements should be thorough to ensure that such placements are justified in terms of the best interest of the child and that they include a clear map of how a placement will be monitored and what services will be delivered.

A developmental approach to statutory social services cannot ignore the risk factors that require a statutory or formal protection intervention, but at the same time will seek and find the capacities and strengths within the child, the family and the community that could counteract the risk factors. Children form part of families and communities and it should be recognised that their rights and needs cannot be understood in isolation (Streak \& Poggenpoel, 2005:3). Mbambo (2004a:39) elaborates that family strengths "are usually made up of the strengths of individual members as well as the connections they have with one another and with people outside the family." Based on a human rights perspective, the relationship with the client is one of respect and collaboration and neither the clients nor the social worker will see them as victims, but as people with strengths and capacities that need to be tapped into during the reconstruction and after-care level of service delivery.

Whilst the statutory service delivery level is directly linked to the individual risk factors that required a statutory intervention, the reconstruction and after-care service delivery level looks beyond the family deficits or weaknesses and taps into one of the most important family preservation values, namely the strengths and resourcefulness of the family (Mbambo, 2004a:39) in order to address the risk factors.

Mbambo (2004b:12) explains that the risk factors are those factors that expose family members and the family as a whole to negative influences, making it difficult for them to cope with the demands of daily life. This, in turn, often leads families to engage in behaviours and practices that can be described as "challenging" or even "problematic". According to Mbambo (2004b:12), risk factors can be divided into two broad categories, namely contextual factors and individual factors. The contextual factors are broad societal and cultural factors, while individual factors include factors that lie within individuals and their interpersonal environments. The resiliency factors, on the other hand, are those that "appear to buffer or support children and families against the negative effects of multiple risk factors" (Mbambo, 2004b:13).

\section{RECONSTRUCTION AND AFTER-CARE LEVEL}

Developmental statutory social services imply integrated services which means that support and reconstruction services should commence the moment a statutory intervention is performed in order to achieve the ultimate aim of family preservation. To address both the contextual factors and individual risk factors the reconstruction and after-care level of statutory social services includes rehabilitation and specialised services such as addiction and mental health services and capacity-building programmes to rectify the impact of individual risk factors as well as prevention and early intervention services that will deal with the contextual factors contributing to the individual risk factors.

In order to work towards this aim, social workers should provide intensive services, including “...activities to promote an environment conducive to the development of the strengths and skills 
of the parent or guardian and the child" (Department of Welfare, 1998:22). It is these "intensive services" that reinforce the integrated developmental perspective to statutory services and thus the challenge to demonstrate a deliberate break from the old social welfare policy paradigm of statutory social service delivery.

According to the Integrated Service Delivery Model (Department of Social Development 2005a:23) prevention services are aimed at strengthening and building the capacity and selfreliance of the client, whilst early intervention focuses on developmental and therapeutic programmes. With regard to the contextual factors, September (2005:29) alludes to the fact that, while child abuse occurs in all communities, it is recognized that children who grow up in poverty, overcrowded homes and unsafe neighbourhoods are at greater risk. Although children should not be removed from their parents due to poverty circumstances (Department of Health Services and Welfare, 1990:6), many abused children who come from a poor family and community, might have a very limited chance of being re-united with their families, if statutory service delivery ignores the factors that influence protection and survival within families and communities, such as family size, food security, livelihoods, availability of extended family to provide care, access to education and health, or other wealth ranking indicators (International Save the Children Alliance, 2003:5). A common denominator for many families is the increasing poverty (International Save the Children Alliance, 2003:14) which leaves many families and communities at risk. An integrated development approach acknowledges these connections and purposefully includes them in its agenda of service delivery (September, 2005:29). On the agenda of developmental statutory services these would refer to the contextual factors that need to be addressed as part of an integrated development plan.

The White Paper for Social Welfare (RSA Ministry of Social Welfare and Population Development, 1997:14) emphasises that social welfare services should be conceived and delivered in a way that treats a child's situation as an outcome of their family and community situation. Developmental statutory services emphasise not only the link between individuals, families and communities, but also the interrelatedness of risk factors and hence the need for integrated service delivery. This is in line with the developmental approach that recognises the relationship between social, economic and political development (Gray, 1997:218) and hence a balance in human, social and economic aspects in programmes (Midgley, 1995:23). September (2005:29) concurs that the individual elements in the expansion and improvement of social welfare services and support such as child care, youth development and family support may include mental health care, economic development, housing, community planning and organising, adult education, job training, and quality of life activities such as neighbourhood safety and recreational programmes. Developmental statutory service delivery can therefore not ignore addressing poverty in the family, nor the at-risk community of which they are part. Short-term assistance with immediate poverty relief such as food parcels and social grants should be replaced with sustainable livelihoods, jobs and adequate housing. Developmental statutory services include strengthening families' capacity to gain access to economic and social resource systems and become selfsufficient and economically independent.

The needs and circumstances of people for protection services vary but interrelate at neighbourhood level, and neighbourhoods therefore have an important role with regard to the protection of children (September, 2005:29). Despite poverty and unemployment, residents were eager to get involved and to improve their neighbourhoods to better protect children (September, 2005:31). A clear demonstration of the integration of "formal protection" services with other protection services in statutory social service delivery is evident in research findings by September (2005:31): "The activities that the [local child protection] forums/neighbourhood sites engaged in 
ranged from cleaning up community sites, supporting children and families through formal child protective processes involving social workers and the courts, engaging with residents and the police to close shebeens, and establishing temporary care and safety homes." A range of reconstruction, prevention and early intervention initiatives and services are captured in these research findings. The parent(s) might, for example, need counselling or treatment for at-risk drinking patterns and accompanied aggressive behaviour (early intervention) in order to prevent becoming dependent and losing a job (prevention). Rehabilitation services are needed to develop self-esteem and empowerment programmes to build capacity in income-generating skills in order to address socio-economic problems such as poverty.

These services link at the core of an integrated plan which should be formulated specifically for the child in his/her alternative placement context, the family in the child's home environment and the community of which they form part.

From a developmental perspective, programmes for the child in alternative care should not be stigmatised by being labelled for "the child in need". Underpinned by the Convention on the Rights of the Child (Office of the High Commissioner for Human Rights, 1990), the basis of the policy change in the Children's Bill (Bill 70D of 2003) is grounded in the right of the child to interventions based on his/her best interest. For example, life skills programmes at schools should reach all children and not only children in need. An adapted version of Australia's Healthy Families Project is an initiative that could be introduced in South Africa, as a combined initiative of the Departments of Social Development and Education (Tomison \& Wise, 1999:6). This school-based project has been successfully implemented in Australia and "teaches children that individuals have the power to change their lives and to develop more constructive forms of parenting than they themselves experienced as children" (Tomison \& Wise, 1999:6). The programme was integrated into the standard curriculum of primary schools and, as a result, the entire community was targeted, and not only at-risk families.

Families who are involved in formal protection services could, for example, be engaged in community programmes with other families who are at risk due to common factors such as poverty and unemployment. In this regard, the neighbourhood-based child protection programmes and initiatives of the Child and Youth Research and Training Programme (CYRTP) at the University of the Western Cape is a South African initiative which has already demonstrated its feasibility and success (September, 2005). Whilst the community develops the capacity to support families that have entered the formal child-protection system, the broader community at the same time benefits from prevention and early intervention programmes on child abuse, parenting and HIV/AIDS.

In view of the increasing demands on social workers for protection service delivery in South Africa, protection social services cannot only be the responsibility of social workers. USA examples of Intensive Family Preservation Services, such as the Homebuilders programme (Wexler, 2002:23; 2003:47), which is designed mainly to prevent the unnecessary out-of-home placement of children through intensive, on-site intervention, and to teach families new problemsolving skills to prevent future crises, is designed for small caseloads for periods of four to eight weeks (Kinney, Haapala, Booth \& Leavitt, 1990:23-37). However, even if caseloads are significantly reduced in South Africa, social workers will not be able to facilitate such a programme on their own due to social work's status of being a "scarce skill". September (2005:33) reports that residents involved in the CYRTP sites were of the opinion that formal service providers seemed to focus mainly on statutory work and therefore did not always have the time to establish and sustain community-level initiatives. Although the reasons for this are not spelt out, it could be assumed that high caseloads and practice demands play a role. What is of more 
significance is the findings of September's (2005:33) research that most of the neighbourhood sites "show growing evidence of good working relationships between community groups and formal service providers".

Another successful community programme in child protection in communities in South Africa is the "Eye of the Child" (Isolabantwana), which was launched on 25 October 1997 as an initiative of the Cape Town Child Welfare Society (Doran, 1999:398). Community members are trained to act as the "eyes" for at-risk children and together with community-based caregivers and social workers they provide integrated protection services, which range from removal from home and placement in the care of caregivers, support and empowerment and capacity-building programmes (Doran, 1999:398).

The Home-Start approach which supports parents and children by providing help at an early stage and early age is another South African programme that could be expanded for developmental statutory social service delivery. Home-Start, an NPO, has been in South Africa since 2001 and is a member of Home-Start International (Home Start South Africa). Home-Start is run mainly by unpaid volunteers, who visit families in their own home for a few hours once or twice a week helping them to avoid crisis and enjoy family life. In the programme volunteers work alongside parents and the approach varies according to the needs of each family. The volunteers do not need formal qualifications, but all must attend an in-depth preparation course. Families may contact Home-Start themselves or be referred by doctors, social workers or other professionals (Home Start South Africa). Home-Start already plays an invaluable role in homes where orphaned children are left to nurture and care for one another. The programme can be explored for the purpose of protection services by recruiting volunteers who follow up on families involved in reconstruction and after-care services and at the same time bring relief to over-burdened social workers.

The potential of community initiatives for standing in for the formal process of protection services as opposed to initiating it from a legal perspective is documented in a study by Landman (2004), where the community decided to engage in monitoring and supporting the child and her family after the child had been found to have been abused by her father. By taking responsibility for the child and the family, the community not only avoided the child being moved into the formal protection system, but also supported the family and encouraged them to engage in community development initiatives.

Within the broader social service delivery framework the CYRTP, "Eye on the Child" and the Home Start programmes can all three be linked to reconstruction and after care services. There are therefore options for integrated developmental statutory social services within the broader social delivery framework. The question is how these possibilities can be expanded within the practice realities of limited resources in the social welfare sector.

Informal discussions with social workers indicate that practice realities such as work demands, lack of resources, the exodus from the profession and the high turn over of social workers in NGOs, make it impossible to provide proper follow-up support services after a statutory intervention has occurred. Furthermore, the difficulty of filling vacant posts in NGOs due to low salaries results in little continuity in the implementation of an integrated, developmental plan, even if there was one in place. Loffell (in Du Toit, 2006) affirms this as follows: "After-care services have already been discontinued for some due to a shortage of money, resources and personnel [social workers].", whilst the ideal is to visit families on a monthly basis. This implies that social workers only visit families when reports are due, as stipulated by the Child Care Act (Act 74 of 1983, as amended in 1999). 
This crisis work approach implies that social workers are unlikely to have the time or energy to apply a human rights approach where they recognise the child, family and community's say in whether the removal of the child would be appropriate within the child's culture and to explore available community protection options. The decision to remove a child is, in many instances, a lonely one made by the social worker who, even with the best intentions to provide the most appropriate services, simply does not have the time to formulate a well-developed, integrated plan of action in collaboration with clients and other relevant role players. Because this does not happen, it means that the next at-risk child in the "at-risk" community is also in line to be removed through a crisis intervention. This scenario reflects the old residual social welfare paradigm for statutory services and reinforces the perception that it is not possible to provide statutory social services from a developmentally-focused approach.

Having argued in this article that developmental statutory social services are an integrated part of developmental social welfare services that can be implemented on the various levels of the social service delivery framework, it becomes evident that it is not because of unclear policy directives, but rather the inability to control and address the variables in the practice environment that holds social workers captured in a residual policy framework for statutory social service delivery. It is therefore not only social policy, but also the attitudes and abilities to implement these polices, that are determining factors for the successful shift to developmental statutory social services. Although it is not the sole responsibility of government to make this happen, the state must utilise its power constructively in order to facilitate an enabling environment that will ensure that the policies it puts in place can be implemented.

\section{CHALLENGES FOR AN ENABLING ENVIRONMENT}

An enabling environment for developmental statutory social services depends on how effectively the following challenges are addressed.

\section{Attitude}

The developmental approach requires a paradigm shift and change of attitude amongst social workers (Mbambo, 2004a:40). Social workers who are currently doing statutory work in exactly the same way as before the adoption of the developmental approach in 1997 are without doubt still providing these services according to the residual social welfare approach. It has been argued in this article that even minor shifts, such as doing casework from a strengths perspective and respecting the rights of children and their parents in the statutory process, would be a significant start in shifting towards the development approach. Without such a mindset and attitude shift, the developmental approach will not be considered as an option and will simply discarded as "being impossible".

Social workers are challenged not to use high caseloads as an excuse for not initiating change in protection social service delivery. This challenge, however, does not mean that the high case loads are acceptable. On the contrary, the challenge includes tackling the root causes of high case loads. Social workers, however, cannot begin to challenge these causes before they deliberately seek and adopt a mindset and attitude shift together with a belief and commitment that there must be a solution, as opposed to being the victim of a system that constantly demands more and more with less and less resources and support. Even in the limiting confines of statutory casework, lack of resources and high caseloads, each social worker has to provide options for decision-making to the family and use a risk-assessment model to assist with decision-making before a decision is made to remove a child. A change of attitude is a prerequisite for developmental statutory case intervention and therefore the excuse of high caseloads and crisis management cannot be condoned. 
From the examples of the CYRTP and the "Eye on the Child", it is clear that there are social workers who are ready to take up this challenge. When the CYRTP decided to develop an integrated neighbourhood-based response to child protection, 70 social workers who represented nine provinces in a national five-day capacity development and training workshop, demonstrated the attitude and willingness to investigate a "new" way of practising statutory social services. They took the national initiative forward by arranging provincial capacity development and training workshops with residents from five selected local areas in each province which resulted in neighbourhood-based child-protection sites/groups in a number of selected local areas (September, 2005:31). They were selected on the basis that they were responsible for child-protection services in the districts where they worked (September, 2005:31) and joined the initiative knowing that "...they would be the 'facilitators and the support system' for the neighbourhood-based groups" (September, 2005:31). Likewise, social workers took the initiative to launch the "Eye on the Child" project and discovered that "[c]hild protection social workers do not need to 'go it alone'." (Doran, 1999:399).

With regard to both programmes, it can be assumed that the social workers' case loads were no different from those of the average social worker in South Africa. The mere possibility of bringing a possible change in their overwhelming workload was motivation enough to become involved.

Although no evaluation or impact study has been done on these initiatives, the research done by September (2005:36) indicates that the community-based child-protection initiatives are working. What is of significance for this debate is that despite the continuing high demand of statutory intervention processes that occupy social workers, they succeeded in launching the CYRTP and "Eye on the Child" initiatives, and communities have been empowered to serve as a support system for families and hence contribute to the prevention of further statutory interventions. Furthermore, there is growing evidence of good working relationships between community groups and formal service providers (September, 2005:33). An attitude that there can and should be a difference in the approach and performance outcomes of statutory social services lays the foundation for tackling the roots of high caseloads.

\section{Analyse the context of high caseloads}

A very high percentage of social workers' caseloads entails statutory work and therefore a focus on children and families. Within the context of developmental social welfare services, this is in itself a huge challenge from the policy directive to shift the focus of service delivery from an individual focus to the masses. The experience of International Save the Children Alliance (2003:7) indicates that the issues confronting children are best understood if social workers first undertake a comprehensive analysis of all the factors that surround the care and protection of children in a particular cultural and social context. As already mentioned, high caseloads are a symptom of causes such as lack of resources, discrepancies in salaries between NGOs and government social workers, and an exodus from the profession to further careers either in another country or outside of the social welfare sector (Du Toit, 2006). Although these factors have been prominent in the media over the past two years, resulting in government recognising social work as a scarce skill in South Africa, the devastating impact has reached crisis proportions for social services in South Africa. Significant challenges lie ahead in addressing the problem of high case loads of social workers. Although NGOs experience unique funding problems stemming from the historical background of the formal welfare in South Africa, it should be recognised that all social work service providers, whether government or non-governmental organisations, have been seriously affected by resource allocations, greater demands for social services and thus high caseloads. When NGOs withdraw services from areas due to a lack of resources, the state has to deliver in those areas, thereby increasing the workload of government employed social workers to 
even higher levels than that of NGOs with the same devastating implications for service delivery within government as in NGOs.

If this is the norm for all social work service providers, it could well be argued that social workers should not be formally charged with unprofessional conduct when they cannot cope with the demands arising from inhuman work loads. During disciplinary hearings an accused social worker generally stands alone in his or her own defence, even if negligence could be directly related to work demands imposed by government, employers or supervisors. At least the work scenario should be taken into consideration as a mitigating circumstance for sentencing purposes.

The question is for how much longer social workers are going to accept being swamped with an ever-increasing workload before they are going to demand an analysis and resolution of the root causes? Whilst social workers' salaries and the funding of NGOs remain an ongoing priority, a thorough analysis is required of the workload of social workers in order to recommend and make meaningful changes that will facilitate developmental statutory and social welfare services in general. Questions need to be answered such as: Why is there an increase of children in need of formal protective services (statutory interventions), if social protection in the form of social grants is continuously being expanded? How can society expect overburdened social workers in government and the NGO sector to take on more statutory work and register as many as 300-500 cases (Floris, 2005; Du Toit, 2006), if the Department of Social Development's policy indicates that a social worker who works with a variety of welfare cases should not have more than 60 files at a given time (Department of Social Development, 2005a)? What services are needed for protection services (including neighbourhood initiatives) and are they recognised by government in service providers' business plans as funding priorities? Is it still an easy option to remove children from home and who is monitoring whether this is the case? How much time, energy, resources and partnership initiatives are invested in developing family and community capacity to take charge of child protection? Are awareness and neighbourhood campaigns contributing to identifying at-risk children and families for statutory intervention? Are families assisted in developing their resiliency factors or is service delivery focused on risk factors only? Is the practice implementation of "integrated social service delivery" and how it applies to all core social service categories clear to service providers? To what extent is "developmental" social welfare service delivery believed by practitioners and academics to be limited to only a few core categories of social service delivery and not applicable to all social welfare services such as statutory social services? How does this belief impact on the training of social work students in preparing them for developmental social welfare practice? Is South Africa successful in its claim of being a developmentally-focused country when it comes to social welfare service delivery?

This list of questions is by no means exhaustive, but merely an indication that the social welfare sector needs answers which are embedded in scientific investigations and research findings in order to make a holistic, long-lasting amendment to social welfare practice in South Africa. The neglect of social services due to the emphasises on social security have been acknowledged by Government's spoke person, Coceko Pakade, Chief Financial Officer, Department of Social Development during a public hearing on the Provincial Budgets and Expenditure Review for the period 2001/2 - 2007/8: "The lack of resources in social service delivery has resulted in, amongst others, poorly developed protection services, inadequate resources to provide other social services to the poor and to promote sustenance of their livelihoods, skills flight of the most essential professionals, and an inability of non-governmental organizations to provide agency services because of lack of resources, which has resulted in closure of such organizations, loss of personnel to government an services reverting back to the state of collapsing" (Department of Social Development, 2005b:3). Taking into consideration that the general trend in Gauteng Province is 
that resources are so limited that social workers struggle to provide basic services (Du Toit, 2006), it is in the interest of the most vulnerable and neglected people in South Africa that social workers demand and participate in a comprehensive national, provincial and local analysis of the statistics of statutory cases to determine the need, the nature and extent of protection services. This is the only accountable way to identify social reform policy directives and service delivery initiatives to curb high caseloads and statutory interventions in favour of child protection and family preservation. A practice model such as suggested by Pittman-Munke (1999) could be utilised for such an analysis. The results of the analysis will contribute to an overall understanding of the link between social issues such as poverty, child abuse and other social ills in society, which in turn will provide a platform to repackage all social service delivery in an integrated, developmental manner.

\section{Integrated plan}

Clear guidelines for what "integrated statutory services" directed at the individual, the family and the community entail for statutory social services need to be developed. These guidelines should incorporate clear directions with regard to the levels of service delivery, the core social services as well as how implementation will be monitored and evaluated to indicate that a family and community is prepared for re-unification.

The guidelines should include at least the following:

- The protection of human rights, i.e. the rights of the child, the family and community with regard to participation in protection decisions and processes;

- Participation strategies for engaging families and communities in decisions and activities;

- Addressing the fundamental causes of family disintegration;

- Respect for social and culture contexts of children and families when placement out of home is considered;

- The fostering of self-reliance, capacity building and empowerment of at-risk families and communities due to causes of children and families being at risk, such as poverty and unemployment;

- Partnerships between government and NGOs, service providers and relevant role players within the community, including business and community structures such as schools and religious organisations;

- Integration of core services within the social service delivery framework of statutory intervention and prevention and early intervention within the context of reconstruction and after-care.

Integral to an integrated plan for social service delivery is clarifying the respective roles of service providers with regard to core service delivery areas and levels. This includes the general versus specialised services debate and more specifically what one social worker can manage when involved in developmental statutory social service delivery.

One of the key findings of a study by Landman (2004:98) was that “...community development and statutory work can be integrated within an integrated developmental approach but cannot be integrated as social service interventions by the same social worker due to the distinctive nature of the two interventions". This is due to the negative impact it has on the trust relationship if a community development worker decides to remove an abused child. Wexler (2003:45-47) 
similarly cautions about early intervention and statutory services due to possible conflicting roles. Within the context of this article, the nature of the involvement of one social worker depends on whether the levels of service delivery form an integral part of the integrated development plan for the family as has been discussed, or whether the specific service or programme activities are targeted distinctively to one level, e.g. prevention.

Within a developmental approach to statutory social services, the social worker who engages in the formal protection service, i.e. the statutory intervention, is only one of many other role players requiring a well-orchestrated plan to ensure effective service delivery. How this social worker engages depends on the design of the integrated plan. The underlying challenge to an effective integrated plan for social service delivery is effective partnerships.

\section{Partnerships}

The development of an integrated plan is a deliberate action and its successful implementation depends on strategic partnerships and coordination directed by visionary leadership. "Partnership" is possibly one of the most abused terms in professional contexts, since it is easily planned but difficult to build and maintain. Lombard and Du Preez (2004:233) elaborate on the various categories of "partnership" and highlight that trust is the underlying fundamental value of all partnership. Government and NGOs need to work very hard on building such trust in order to jointly take developmental social services forward in South Africa. One of the burning unresolved issues after 1994 which impacts seriously on social service delivery according to Loffell (in Du Toit, 2006) is the tension between NGOs and government with reference to what is understood by transformation, which in many instances results in a deadlock and further impacts on the decreasing abilities of welfare organisations. What is significant for the way forward is Loffell's statement that " $\mathrm{t}] \mathrm{h}$ ere has never been a discussion on what exactly the roles are of the government, the business and private sectors, and NGOs [with reference to transformation]" (in Du Toit, 2006:11). Finding consensus and common understanding, based on open dialogue holds a huge challenge for developmental social services in South Africa.

NGOs have long acknowledged they prefer not to be funded solely by government for various reasons such as retaining their independence and their capacity to challenge government (Bar-On, 1999:44-45; Lombard \& Du Preez, 2004:237). The state does not employ the social workers in the NGO sector and the responsibility for service conditions and remuneration rests with the employer. This needs to be addressed and may need a change in the partnership configuration to contracting and not of subsidisation. If there are numerous service providers for child-protection services, this process could result in a rationalisation of service providers.

NGOs remain challenged to shift social welfare service delivery to a more business-like orientation. Engaging the business sector, not only for funding, but for this purpose is a step into the right direction. September (2005:35) confirms the business-focus proposition by saying that developing good relationships with the business sector is essential, whilst at the same time cautions that the business sector should not only be approached when donations are needed.

Within a developmental context, the focus of all role players should first and foremost be on the vulnerable who have the right to receive effective services from service providers when they need them. Without additional funding, effective delivery of statutory services and the continuum of care services will be undermined (Streak \& Poggenpoel, 2005:17). NGOs have the infrastructure to reach the poorest of the poor with the poverty-alleviation money, which every year elicits parliamentary debates because it has not been spent. Increased funding for intensive protection services would lead to long-term savings, in terms of children who are no longer placed in 
alternative care and families who are no longer dependent on government grants (Wexler, 2002:33; 2003:61-63).

In statutory social service delivery the need for partnerships should be no less than in the case of community interventions. September (2005:29) indicated that neighbourhood child-protection initiatives work better if they are part of a comprehensive approach to community development. This involves the development of collaborative partnerships between local structures, service providers, primary institutions and ordinary citizens around a plan to route the overall well-being of children and families (September, 2005:29). The same collaborative partnerships apply to statutory social services.

\section{Conferences and debates}

Embedded in all of the above challenges is the need for dialogue, sharing of practice and research experiences, and reaching consensus on options to change the face of statutory social service practice in South Africa. To achieve the shift to the development focus in statutory social service delivery requires similar leadership, passion, energy and time that the social welfare sector demonstrated in arriving at the adoption of the White Paper for Social Welfare (RSA Ministry of Social Welfare and Population Development, 1997).

The only way to find long-term answers to questions raised in this article is to bring the experts and leaders in the field of child protection services together to present and discuss their experiences, and share results of successes. Then guidelines should be drafted for piloting new strategies that incorporate reasonable demands with regard to the workload of social workers and resources, but above all, promote thorough research, support and incentives for seeking best practices for comprehensive, integrated protection services.

The International Save the Children Alliance (2003:7) emphasises that good practices and programmes that can be scaled up need to be identified as a matter of urgency for the increasing need for children to be cared for as follows: "We need to raise awareness, understanding, public debate and interest surrounding these issues through research, conferences, public hearings and articles". It is the intention of this article to initiate such a dialogue.

\section{CONCLUSION}

Statutory interventions form part of protection services which are an integral part of the "integrated basket" of developmental social welfare services. Since "[t]he shift of social welfare towards a development paradigm is based on a constitutional, policy and legislative mandate" (Patel, 2005:3), no part of social welfare service delivery, including statutory social services and casework, should continue from a residual social welfare approach which is embedded in colonialism, discrimination and apartheid.

In responding to the call of the International Save the Children Alliance (2003:1) that "we need to find better solutions for helping children affected by poverty, conflict and HIV/AIDS" lies a challenge that stretches far beyond protecting children by merely removing them from home by means of a statutory intervention. Children have the right to live in a caring family environment (International Save the Children Alliance, 2003:4). In the face of the HIV/AIDS pandemic it is even more of a challenge and an imperative to preserve the "family" context for children.

It is social policy, influenced by culture, history, politics and many other contextual factors that determines the type of support a child will receive (International Save the Children Alliance, 2003:1). Protection services, like all other social services, should be informed and guided by policy and not be dictated by practice realities such as high caseloads, lack of resources and 
ineffective partnerships and leadership. This conclusion links closely with remarks by the First Lady Zanele Mbeki during a conference attended mainly by government and community workers in December 2005 in George: "We should not make a welfare state and call it a developmental state" (Boyle, 2005:1). During this conference Mrs Mbeki said: "My own experience is that there were serious shortcomings in the design of pro-poor policies, as well as the design of delivery mechanisms in several key areas" (Boyle, 2005:1).

Within a developmental state embedded in a human rights approach, the obstacles in the way of achieving this goal should be eliminated. Streak and Poggenpoel (2005:5) state that "government is legally obliged to develop laws, policies, programmes and budgets in a way that advances the realisation of these rights. As such, policy development, budgeting and service delivery in the realm of social welfare services must be informed by these child rights and obligations". NGOs and other role players should take co-responsibility in developing policies, programmes and budgets that will facilitate developmental social services in South Africa. At the same time it has to be realised that the realisation of the norms and standards in the Integrated Service Delivery Model (Department of Social Development, 2005a) has to be on a long-term basis. Even if the state provides all the money required for service delivery, South Africa does not produce the number of social workers required to provide adequate social services in the country.

The need for a ten-year social services resource plan mooted by the national Department of Social Development becomes crucial for the provision of services and to meet the critical immediate and long-term demands for statutory interventions. Despite all of the shortcomings mentioned in attaining developmental service delivery in statutory work, the basic principles of respect for human rights and the change of attitude required to provide any type of social work services need to be preserved. Change of attitude costs nothing; every client served by government and NGO social work service providers should be treated with dignity, respect, acknowledgement of the strengths of the family and provided with options. These are basic core values of the profession and need to be emphasised and reinforced.

This article has argued that, despite the policy directives for developmental social services being in place, the enabling environment for delivery mechanisms of developmentally statutory services are inhibited by very specific challenges. Because statutory social work forms such a large percentage of social welfare services, it would be a huge step forward if the challenges as outlined in this article are prioritised for the social welfare agenda in South Africa in securing an enabling environment for developmental statutory social services. The White Paper for Social Welfare (RSA Ministry of Social Welfare and Population Development, 1997) and subsequent policies provide sufficient evidence that South Africa has the leadership qualities and champions to be a world example of integrated developmentally-focused social welfare.

\section{REFERENCES}

BAR-ON, A. 1999. Non-governmental organizations: Salvation or perdition? Social Development Issues, 21(3):22-30.

BILLUPS, J.O. 1990. Toward social development as an organizing concept for social work and related social professions and movements. Social Development Issues, 12(3):14-26.

BOYLE, B. 2005. First Lady: State has failed the poor. Sunday Times, 11 December: 1.

DAVIDS, M. 2005. Personal discussion. 3 February.

DEPARTMENT OF SOCIAL DEVELOPMENT. 2004a. Policy on Financial Awards to Service providers. 
DEPARTMENT OF SOCIAL DEVELOPMENT. 2004b. National Policy for Families. $3^{\text {rd }}$ Draft, June 2004.

DEPARTMENT OF SOCIAL DEVELOPMENT. 2005a. Integrated Service Delivery Model. December.

DePartment of SOCIAL DEVElopMent. 2005b. Public Hearings on the Provincial Budgets and Expenditure Review - 2001/02 to 2007/08. Presentation by Coceko Pakade, Chief financial Officer, Department of Social Development. Media Release by Michael Fumarola, Tuesday, 18 October 2005.

Department of Welfare. 1998. Information Guide for Social Workers on the Practical Application of the Child Care Act 74 of 1983, as Amended and Regulations. Cape Town: CTP Book Printers (Pty) Ltd.

Department of Welfare. 1999. Financing Policy for Developmental Social Services. Notice 463 of 1999. Government Gazette, 405(19888). Pretoria: Government Printers.

DORAN, L. 1999. "Eye on the child": "Isolabantwana" - A community-based Child Protection Programme. Notes from practice. Social Work/Maatskaplike Werk, 35(4):396-399.

DU TOIT, P. 2006. Welskynstaat, nie welsynstaat. Beeld, 31 January: 11.

ELLIOTT, D. 1993. Social work and social development: Towards an integrative model for social work practice. International Social Work, 36:21-36.

FLORIS, J. 2005. As sy lag, kry ander hoop: Maatskaplike werker moet bontstaan maar sien resultate. Beeld, 15 February.

GRAY, M. 1997. A pragmatic approach to social development (Part 1). Social Work/Maatskaplike Werk, 33(2):210-222.

GREEN, S. \& NIEMAN, A. 2003. Social development: Good practice guidelines. Social Work/Maatskaplike Werk, 39(2):161-181.

HOME-START SOUTH AFRICA. Brochure. Boksburg: Minuteman Press. Available: http://www.home-start-int.org.

INTERNATIONAL SAVE THE CHILDREN ALLIANCE. 2003. A Last Resort: The growing concern about children in residential care. [O]. Available: www.savethechildren.net [Accessed on $09 / 04 / 05]$.

KINNEY, J., HAAPALA, D.A., BOOTH, C. \& LEAVITT, S. 1990. The Homebuilders Model. In: TRACY, E.M., HAAPALA, D.A., KINNEY, J. \& PECORA, P.J. Intensive family preservation services: An instructional sourcebook. Cleveland: Mandel School of Applied Social Sciences.

KLEIJN, W.C. 2004. A developmental approach to statutory social work services. Pretoria: University of Pretoria. (MSD Mini-Dissertation)

LANDMAN, L. 2004. Integrating community development and statutory social work services within a developmental approach. Pretoria: University of Pretoria. (MSD Mini-Dissertation)

LOMBARD, A. 2005. Impact of social services on human, social and economic development and the promotion of human rights in South Africa. Social Work/Maatskaplike Werk, 41(3):209227. 
LOMBARD, A. \& DU PREEZ, J. 2004. Challenges for building partnerships in social development. Social Work/Maatskaplike Werk, 40(3):232-245.

MBAMBO, B. 2004a. How to ride a wave when the tide turns? ChildrenFirst, September/October, 8(57):39-40.

MBAMBO, B. 2004b. Building buffers against risks factors. ChildrenFirst, July/August, $8(56): 12-13$.

MIDGLEY, J. 1995. Social development: The developmental perspective in social welfare. London: SAGE Publications.

NATIONAL COALITION FOR CHILD PROTECTION REFORM. 2003. Issue Paper 6: Child Abuse and Poverty. [O]. Available: http://www.nccpr.org/newissues/6.html [Accessed on 18/08/04].

OFFICE OF THE HIGH COMMISSIONER FOR HUMAN RIGHTS. 1990. Convention on the Rights of the Child. Adopted and opened for signature, ratification and accession by General Assembly resolution 44/25 of 20 November 1989, entry into force 2 September 1990, in accordance with article 49. [O]. Available: http://www.unhchr.ch/html/menu3/b/k2crc.htm [Accessed on: 2006/04/29].

PATEL. L. 2005. Social welfare and social development in South Africa. Southern Africa: Oxford University Press.

PITTMAN-MUNKE, P. 1999. Bridging the divide: The casework policy link. Journal of Sociology and Social Welfare, XXVI(2):203-216.

POTGIETER, M.C. 1998. The social work process: Development to empower people. South Africa: Prentice Hall South Africa (Pty) Ltd.

REPUBLIC OF SOUTH AFRICA. 1983. The Child Care Act. Act 74 of 1983. Government Gazette, (8765). Pretoria: Government Printer.

REPUBLIC OF SOUTH AFRICA. Department of Health Services and Welfare. 1990. Verslag van die Komitee van Ondersoek na Pleegsorg van Kinders. Pretoria: Government Printer.

REPUBLIC OF SOUTH AFRICA. Minister of Social Development. 2003. Children's Bill. Bill 70D of 2003. Available: http://www.info.gov.za/documents/bills/index.htm [Accessed on: 29 April 2006].

REPUBLIC OF SOUTH AFRICA. Ministry for Welfare and Population Development. 1997. White Paper for Social Welfare. Notice 1108 of 1997. Government Gazette, 386 (18166). Pretoria: Government Printers.

SEPTEMBER, R.L. 2005. Protecting children where it matters most: In their families and their neighbourhoods. Social Work/Maatskaplike Werk, 41(1):27-37.

STREAK, J. \& POGGENPOEL, S. 2005. Towards social welfare services for all vulnerable children in South Africa. A review of policy development, budgeting and service delivery. Children's Budget Unit. IDASA. Budget Information Service. 31 March.

STURGEON, S. 1998. The future of casework in South Africa. In: GRAY, M. (ed). Developmental social work in South Africa: Theory and practice. Claremont: David Philip Publishers (Pty) Ltd. 
TERMINOLOGY COMMITTEE FOR SOCIAL WORK. 1995. New Dictionary of Social Work. Cape Town: CTP Book Printers (Pty) Ltd.

TOMISON, A.M. \& WISE, S. 1999. Community-based Approaches in Preventing Child Maltreatment. Child Abuse Prevention, 11.

VAN NIEKERK, H.J. 1998. Child welfare legislation and practice. Durbanville: Van Gent Publishers.

WEXLER, R. 2002. Emerging from the shadows: A 12-step program to fix DCF. Alexandria VA: National Coalition for Child Protection Reform. [O]. Available: http://www.nccpr.org/reports/emerging.doc [Accessed on 22/10/04].

WEXLER, R. 2003. The road less travelled by: Toward real reform of child welfare in Missouri ( $2^{\text {nd }}$ ed). Alexandria VA: National Coalition for Child Protection Reform. [O]. Available: http://www.nccpr.org/missourireport5.doc [Accessed on 24/08/04].

ZASTROW, C. 2004 . Introduction to social work and social welfare: Empowering people $\left(8^{\text {th }}\right.$ ed). USA: Thomson Brooks/Cole.

Prof Antoinette Lombard, Professor and Head, Department of Social Work and Criminology, University of Pretoria, Pretoria, South Africa and Ms Willemien Kleijn, Postgraduate student in the Department of Social Work and Criminology, University of Pretoria, Pretoria, South Africa. 